International Research Journal of Management, IT \& Social Sciences
Available online at https://sloap.org/journals/index.php/irjmis/
Vol. 5 No. 4, July 2018, pages: 98 105
ISSN: 2395-7492
https://doi.org/10.21744/irjmis.v5n4.271

\title{
Shifting on Usik Liau Game in Wara Ceremony towards Hindu Kaharingan Society of Dayak Dusun
}

\author{
Derson $^{a}$ \\ I Ketut Subagiasta ${ }^{\text {b }}$ \\ Ida Bagus Dharmika ${ }^{c}$
}

Article history:

Received: 27 February 2018

Revised: 26 June 2018

Approved: 28 July 2018

Published: 31 July 2018

Keywords:

Shifting;

Tradition;

Dayak Dusun;

Wara Ceremony;

Hindu Kaharingan;

\begin{abstract}
The Hindu Kaharingan society of Dayak Dusun in South Barito watershed has a very strong divine insight as reflected in the aspects of their lives. The religion was not in the major religions, Islam, Christianity, Catholicism, Buddhism, and Hinduism. It was not limited to the world of its tribal environment. It was related to the essential for its own ancestors. Hindu doctrine was often seen generally regarding the implementation of the religious ceremonies. It was called yadnya. It defined as the sacred sacrifices were conducted sincerely. Due to the diversity for each activity, it was done in accordance with the concept included Desa (place), Kala (time), and Patra (situation and condition). Kaharingan Hindu society was located in the South Barito watershed. There was a mandatory ceremony to be performed. The Liau ancestors can be detached from suffering and misery and could reach the realm of eternity. It was Lummut Mountain. Usik Liaugame still exists in the Hindu Kaharingan society although it was often classified that the game as a deviant behavior. Due to it was toward the values of Hinduism and positive law. The religious meaning values of the game were forwarded to the ancestors. The now game implementation ceremony has undergone a shift. The society was bound to the tradition. It was assumed that the game was a pure traditional ceremony was inserted with a gambling game made the event to do business for the momentary benefit. The ceremony was mandatory to be implemented as a form of devotion to his ancestral devotion.
\end{abstract}

2395-7492@ Copyright 2018. The Author. This is an open-access article under the CC BY-SA license (https://creativecommons.org/licenses/by-sa/4.0/) All rights reserved.

Author correspondence:

Derson,

IAHN-TP Palangka Raya, Indonesia

Email address: derson_rkamil@yahoo.co.id

a IAHN-TP Palangka Raya, Indonesia

${ }^{\mathrm{b}}$ IAHN-TP Palangka Raya, Indonesia

${ }^{c}$ University of Hindu Indonesia, Indonesia 


\section{Introduction}

The Hindu Kaharingan Society of Dayak Dusun in the South Barito watershed believe that the myths about the immortality realm (macrocosm) and the universe (microcosm) are in the real life. Therefore, the every human being must position themselves to attain the immortality realm or the nature macrocosm. Adi, T. N. (2008), viewing the existence of the eternal realm is the fundamental Hindu Kaharingan society belief of Dayak Dusun in the South Barito watershed to various forms on the ceremony.

One of the Hinduism teachings is often seen in Hindu society generally about religious ceremonies implementation i.e., yajna is the sacrificial offerings sincerely. Due to the diversity consist of each activity, it is conducted in accordance with the concept of Desa (place), Kala (time), and Patra (the circumstances of the situation and conditions). Hindu Kaharingan society in the South Barito watershed, wherein, there is a ceremony that must be implemented. Liau ancestors of Dayak Dusun society can be separated from the free for samsara, and can reach eternity realm is Lumut Mountain. Usik Liau implementation on Wara ceremony as is part of a yad, namely devotion, sincere sacrifice for the welfare purpose, peace, and the universe sustainability (Tim Pengusundan, 1996: 96-97). The Hindu Kaharingan society of Dayak Dusun in South Barito watershed always strives to improve the status of their ancestral spirits through a Wara ceremony. Wara ceremony is to sanctify for the Liau ancestor. Thus, Liau ancestors can be detached from suffering and attain eternal realm forever.

It is interesting to be studied Wara ceremony. It is a Usik Liau as well as an ancestral game implemented through the game or traditional by Kannong Wadian Wara as the leader ceremony become a joy symbol describes the natural living of the Liau ancestors who are in Lummut mountain. It is believed to be a sanctuary for the Liau ancestors before reaching the immortality nature, Kalong Bulau. In the era, Usik Liau game has the religious value meaning. It is experienced the shift then became Usik Liau Profan which is identified with gambling as if it is not be questioned by society. Due to they have Usik Liau game is a pure custom ceremony and become a tradition (Kniten, I. P. P. P., \& Gunanta, I. N; 2005).

Usik Liau game in the Wara ceremony is not a traditional ceremony or tradition. Hindu Kaharingan religious ceremony has been conducted through the generations as a devotion to their ancestors and never known gambling terms. The gambling was thrown into the Usik Liau. In order to make the ceremony implementation more lively and there are certain purposes that can benefit themselves. Usik Liau is a game by the Liau ancestors that was implemented through traditional games by Kannong Wadian Wara. Mertha, I. K. (2010), Moleong, L. J. (1999), Mudhofir, A. (1996), the reality of the Usik Liau game is implemented by the City (boss of the game) as a promoter who can afford regarding the finance for Wara ceremony activities.

It is not surprising if the Usik Liau game is synonymous with gambling. It is often forcibly dissolved by the police. The boss game was arrested even imprisoned. The reality is still happened occurred in Hindu Kaharingan of Dayak Dusun society in the South Barito watershed openly. This phenomenon raises the question. "Why Usik Liau game is difficult or even impossible to be abolished from the Hindu Kaharingan tradition of Dayak Dusun in South Barito watershed?" regarding the aspect will be analyzed the problems and hopefully can find a formulation that can be used as an alternative solution to the parties. Related to the parties, to reduce the current problems unlike providing explanation/understanding is by Kannong Wadian Wara. Dharmayuda, I. M. S. (2001), towards the Hindu Kaharingan society of Dayak Dusun itself as well as to the general public about the meaning and meaning contained in the Usik Liau game. There are no errors occur different views and perceptions.

\section{Research Methods}

The present study is applied a qualitative method. Ali, H. S. (2002), the data was collected based on the documentation. The documentation data included the phenomenon that was occurred in Wara ceremony. The data were presented elaborated, explained and paraphrase descriptively. The conclusion of this paper was obtained in accordance with the fact that happened in the current completed the study (Artadi, I. K.; 2004).

\section{Results and Analysis}

The occurrence factors shifting on the Usik Liau game in Wara ceremony conducted by the Hindu Kaharingan society of Dayak Dusun in South Barito watershed included; (1) the actors are from the society itself (internal actors), mostly Hindu Kaharingan society. Donder, I. K. (2005), due to when playing Usik Liau Profan game is identical with

Derson, -, Subagiasta, I. K., \& Dharmika, I. B. (2018). Shifting on Usik Liau game in Wara ceremony towards Hindu Kaharingan society of Dayak Dusun. International Research Journal of Management, IT and Social Sciences, 5(4), 98-105. https://doi.org/10.21744/irjmis.v5n4.271 
gambling game, mostly Hindu Kaharingan society itself seems not understand the rules that have been made. Therefore, what they do can affect the social environment. It is unlike a lack of brotherhood sense, ignoring local culture, not looking for full happiness, and not looking for the good deeds and rewards. Due to carrying out Wara ceremony merely look for a profit. It is being based on a sincere action of offerings. The actors are from outside the society (external actors). Unlike, some boss game acts as a promoter able to finance or patron for the implementation of Wara ceremony, with the certain intentions. (2) The social life context of Hindu Kaharingan of Dayak Dusun has a social value respected to the attachment or relationship between human in the society. The social values are always applied in the social life e.g., kinship, togetherness, and deliberation (Geertz, C.; 2001).

The social status was obtained in some ways recognized by local people who can demonstrate the advantages of having knowledge of adat (custom) related to the ceremony world. The social value can be harmonious, if in the society mutual respect and mutual respect between societies to another, and vice versa can cause conflict. If the social value is not applied or obeyed well unlike the basis in social life, the most dominant social values applied by the Hindu Kaharingan society of Dayak Dusun in the South Barito watershed is still traditional social values included solidarity, consensus, and mutual cooperation. (3) The low awareness of the prevailing customary law, it defined that people still have strong belief systems towards the preservation of the local culture. However, sometimes the custom is a very strongly applied in the society. Thus, the many rules must be obeyed and finally, there was a group of people wants to change the rules become customary, not to get sanction or in the form of a customary fine. According to the societies unlike customs were merely customary due to them have no clear legal basis. Though this customary law was quite clear, although not to be written the society remains obedient and obedient to the rules. (4) The lack of understanding for the Usik Liau game sometimes can be regarded as something positive or considered something negative, depending on the extent to which people respond. There are some groups of people who think Usik Liau game as something that was bad. For instance, the view is motivated by the circumstances in which the culprit for all division forms within society can lead to social disintegration. The most of the people are overwhelmed, the Usik Liau game is considered a traditional ceremony inserted gambling game that is often legalized. Even, regarding a group of Hindu Kaharingan, offering to several boss game to cooperate openly some gambling games in the hope of earning a lot of profit. (5) The cultural value of Hindu Kaharingan society of Dayak Dusun, in the past, most of their lives were farmed to collect forest products and as small fishermen. Their residence is generally on the banks of the river. The small group life built a village, which eventually developed into a village or rural area. Ranjabar, J. (2015), in everyday life, they help each other out.

It was evident when the season of mиаu parei (planting rice) and their harvest always work together to help each other. In every society, there was always the elder and honorable. Gepu, W., Suda, I. K., \& Suyasa, I. M. (2018), due to the person who was elderly was the one whom they consider fair, honest, wise, courageous, patient, and respectful of the others opinions. They were always obedient to all rules that have been agreed upon. (6) The Hindu Kaharingan society of Dayak Dusun still runs various social activities. Due to the cultural patterns of their lives still cling to traditional cultural patterns that still remain pure e.g., openness and mutual help life or gotong-royong. If there were families or other people affected by the disaster that needs to get help. The culture unlike is not strange any more, due to their life at first was life from descending or one house or known for living in the lekang house (longhouse). Suharsimi, A. (2006), the culture pattern for them have gradually shifted due to the influence of the influx of modern cultures. The traditional culture was considered to be an obstacle, therefore, the culture was a culture that was not feasible to be applied with the development of the current era. (7) The socio-cultural mobility for Hindu Kaharingan society of Dayak Dusun in the South Barito watershed has shifted towards modern cultures. Haryanto, S. (2015), ff the societies did not want to maintain their traditional cultures, however, on the contrary, if the culture can be maintained, then it will not experience a shift towards the traditional culture that is maintained until now.

The process of shifting on Usik Liau game has several components, included: (a) in the ordering process of the implementation of the Usik Liau game can be grouped into three stages. They were in the preparation stage, the main stage, and the final stage. The stages will follow how the Wara ceremony procedure takes place, with a length of activity for a week. (b) The Usik Liau game type has two categories. It is still pure and the Usik Liau Profan game. Here is the table of the moving process of the Usik Liau game. 
Table 1

The process of the Usik Liau game.

\begin{tabular}{|l}
\hline The characteristics of the pure Usik Liau game \\
- Implementing the Usik Liau game based on \\
Wara ceremony, the basis of their own ability, \\
without being defeated by others. \\
- Implementing the Usik Liau game in Wara \\
ceremony, the basis of a sincere, without \\
getting rewards and profits. \\
- The one who was actually an ancestor of the \\
Hindu Kaharingan ancestors \\
- The execution time is only 7 (days) 7 (night) \\
i.e., approximately 1 (one) week of ceremonial \\
ritual activity. \\
\\
The Usik Liau game types can do, and there is no \\
gambling game motif. \\
- Saung manu Liau (fighting chicken between \\
Kannong and the family who hold Wara \\
ceremony \\
- Saramin Liau (mirrored in a jar or water \\
bucket) \\
- Gasing Liau (gasing game play) \\
- Kaleker Liau (marbles of ancestors) \\
physical sepak tampihak Liau (fighting \\
- Popok osi Liau (physical figthing) \\
- Sansiwo Liau (thrown coconut fiber) \\
Torou sawui taareng or lahiyat Liau (flush with \\
water and powder) \\
- Tinnak alu and tari tinnak balon dances (sacred \\
dance)
\end{tabular}

The characteristics of the Usik Liau Profan game

is identical gambling game

- Implementing the Usik Liau game is not based on their own ability, but financed by others like Boss game

- Implementing the Usik Liau game is not based on a sincere and always looking for profit

- Those who are being ceremony are sometimes not Hindu Kaharingan ancestors

- Implementation time of 14 (fourteen) days 14 (fourteen) nights, even up to 1 (one) month of ceremonial activity

The game types of the Usik Liau Profan Game is a gambling game motif.

- Saumg Manu Liau Profan (game of chicken by Boss game) for 2 (two)

- Saramin Liau Profan (5 card) or arena

- Gasing Liau Profan (whirling dice game) of 5 (five) arenas or arenas

- Kaleker Liau Profan (gameplay dice) of 9 (nine) stalls or arena

- Timmai Galang Liau Profan (throw a bracelet) for 2 (two) stalls or arena

- Ruweh Dime Liau Profan (two-fifths) as many as 2 (two) arenas, and other games.

The lack of brotherhood sense due to performing the ceremony was always individual and reduce the sense of the mutual cooperation among Hindus Kaharingan own. They do not comprehend thoroughly the meaning of the Usik Liau game in Wara ceremony. Carrying out the ceremony is not based on a sincere. The Implementation tends to be business. It was the implementer of the ceremony invites cooperation with the boss game as the promoter to finance the implementation for Wara ceremony. In making the following agreements or agreements: (1) The funder or promoter is willing to spend funds for ceremonial capital in the range IDR. 300.000.000 (three hundred million rupiah), up to IDR. 600.000 .000 (six hundred million rupiah), but the ceremony organizer must be able to return the capital and added $25 \%$ or $50 \%$ of the profits levied from several game types. (2) The levy of one food and drinking stall was IDR. 500.000. (3) A car parking fee charged IDR. 50.000, and motorcycle IDR. 10.000. (4) One levy of dice gurak IDR. 300.000 and plus excise taxes IDR. 75.000 for morning and IDR. 75.000 for the night. (5) The levy one bracelet of one bracelet set IDR. 300,000. (6) the cost of distributing lights to a single fruit stall, and a gambling gaming venue for IDR. 250.000 for one piece. (7) The splendor of the gambling games, Setiadi, E. M., \& Kolip, U. (2011), from various social life from children's level to parents. The influence of the Usik Liau profan game to behaviors unlike (a) based on the behavioral life that was initially hospitality, which turned into a life of harsh behavior, due to the social jealousy between fellow Hindu Kaharingan. (b) The household relationships become messy and can lead to divorce. (c) The workaholic decrease becomes lazy. (d) It often leads to fights between fellow players as well as with the Boss game. (e) Unlike drunken liquor, economic participation in the game was just an escape. As for the level of the Usik

Derson, -, Subagiasta, I. K., \& Dharmika, I. B. (2018). Shifting on Usik Liau game in Wara ceremony towards Hindu Kaharingan society of Dayak Dusun. International Research Journal of Management, IT and Social Sciences, 5(4), 98-105. https://doi.org/10.21744/irjmis.v5n4.271 
Liau game, first mandatory to conduct Ngalangkang ceremony for one day one night with the implementation of three consecutive years, new ceremony Wara ceremony held. The ceremonies were for Wara Tutui Kanen 3 (three) days 3 (three) nights. The ceremony is for Wara Tutui Kanen for 5 (five) days 5 (five) nights.

The four ceremonies of Wara ngariring jabing salimbat about 7 (seven) days, 7 (seven) nights (1) The meaning of the game is like the meaning of solidarity, responsibility, culture, religious, and social ties, (2) The execution place for Usik Liau game, Maman, K. H. (2006), It can only be conducted within the house or around the area wherein the Wara ceremony is held. Due to in the area have got recommendation from various related to institution such as head of household, head of the village, Damang, Pangulu and Custom Mantir, MK-AHK), the District-level Hindu Kaharingan Religion Assembly (MR-AHK), the District-level Hindu Kaharingan Religion Council (MD-AHK), police officers from Kapolsek (the head of sector police) and Kapolres (the head of resort police) who are responsible for the security of the Wara ceremony. (3) The perpetrator is the most basic person directly involved in carrying out Wara ceremony, unlike grandchildren and family members (Martono, N.; 2011).

The implications of shifting on due to several factors: First, the social-economic factors. The Hindu Kaharingan society of Dayak Dusun, the upper-middle-class economy often performs the Wara ceremony in a magnificent and massive manner, costing too much. Whereas, the average society income is only IDR. 500.000 per month, and even then it is not certain. Due to the most of the Dayak Dusun society comes from farmers, traders, and fishermen. This is what causes the society to carry out Wara ceremony is not based on a sincere. Therefore, it was carrying out the ceremony is only based on for-profit and doing business. Second, Dependence from others (Boss game). In the current era, wherein the social demands are more urgent and difficult, thus, it ultimately can affect the life of middle-class society down. The Hindu Kaharingan society of Dayak Dusun people performs Wara ceremony, no longer like the previous era. Due to when carrying out the ceremony, they will not trouble and confuse with their cost of the problem will be too large. The now some certain people from Hindu Kaharingan own society who want to cooperate with Bandar as the promoter deliberately insert gambling game into the game of Lifestyle Liau only a momentary interest.

Thirdly, the transformation of traditional culture into modern culture, the society firstly only used traditional clothing, as simple as possible that can still be used for every day. Along with the development they currently use expensive clothes, just for following the trend and wearing according to be emotional. Trust. In ancient times, the most people teachings their ancestors, but now they instead put forward the logic with real evidence. Culture. In the past, people knew that they were helping each other or gotong-royong if some people got into trouble, now the culture is slowly getting abandoned. Art. Yesmil, A. Adang. (2013), the society instead chooses the art of outsiders, rather than their own culture. Politeness. The old people habits for the older people are obliged to be respected or respected, now even the old respect the young and the resident. In the past, the people lived in traditional houses, now traditional houses are rarely found. Due to the society has turned the traditional house into a modern house and the Four Factors of education society of Dayak Dusun. To know the education average level of Hindu Kaharingan society of Dayak Dusun is still practically low. It is almost always stated that the population majority does not finish primary school. Therefore, the illiteracy rate for the old class is greater. Veeger, K. J. (1985), Wiranata, I. G. A., \& SH, M. (2005), even some of the old are still productive at this time never felt stuck in elementary school. Firstly factor, infrastructure, secondly low awareness about education, and thirdly is difficult to continue education.

\section{Conclusion}

It can be concluded. Firstly, the factor is for Usik Liau game getting a shift Wara ceremony was due to the game actor, social values, low awareness of the prevailing customary law, lack of understanding, social culture value, socialcultural pattern, and social culture mobility. Secondly, the process of game shifting in Wara ceremony is the implementation stage, the game type is divided into two parts (1) Usik Liau game is still pure and profanity, the process of Usik Liau Profan game, level of Usik Liau game, the meaning of Usik Liau game, game place, and game players. Thirdly, the implication is occurred a game shifting on Wara ceremony is caused by a socio-economic factor, depends on the others boss gambling, traditional cultural transformation into modern culture, and education of Hindu Kaharingan society of Dayak Dusun. The components are influenced of shifting for Usik Liau game in Wara ceremony.

Conflict of interest statement and funding sources

The authors declared that they have no competing interest. The study was financed by personal funding. 
Statement of authorship

The authors have a responsibility for the conception and design of the study. The authors have approved the final article.

Acknowledgments

The author would like to thank the editor of IRJMIS for their support, valuable time, and advice.

Derson, -, Subagiasta, I. K., \& Dharmika, I. B. (2018). Shifting on Usik Liau game in Wara ceremony towards Hindu Kaharingan society of Dayak Dusun. International Research Journal of Management, IT and Social Sciences, 5(4), 98-105. https://doi.org/10.21744/irjmis.v5n4.271 


\section{References}

Adi, T. N. (2008). Identitas Kultural dan Televisi Lokal (Studi Tentang Konstruksi dan Representasi Identitas Kultural dalam Tayangan Banyumas TV) (Doctoral dissertation, Tesis: Program Pascasarjana Universitas Sebelas Maret, Surakarta).

Ali, H. S. (2002). Metodologi penelitian agama: pendekatan teori dan praktek. PT RajaGrafindo Persada.

Artadi, I. K. (2004). Nilai Makna dan Martabat Kebudayaan. Denpasar: Sinay.

Dharmayuda, I. M. S. (2001). Desa adat: kesatuan masyarakat hukum adat di Propinsi Bali. Upada Sastra.

Donder, I. K. (2005). Esensi bunyi gamelan dalam prosesi ritual Hindu: perspektif filosofis-teologis, psikologis, sosiologis, dan sains. Paramita.

Geertz, C. (2001). Agama sebagai Sistem Budaya. Yogyakarta: Qalam.

Gepu, W., Suda, I. K., \& Suyasa, I. M. (2018). Religious conversion towards Hindu Kaharingan to Christianity. International Journal of Linguistics, Literature and Culture (IJLLC), 4(4), 25-37.

Haryanto, S. (2015). Sosiologi Agama dari Klasik Hingga Postmodern. Ar-Ruzz Media, Yogyakarta.

Kniten, I. P. P. P., \& Gunanta, I. N. (2005). Tinjauan tabuh rah dan judi.

Maman, K. H. (2006). Metodologi Penelitian Agama: Teori Dan Praktik.

Martono, N. (2011). Sosiologi Perubahan Sosial: Perspektif Klasik, Modern, Posmodern, dan Poskolonial. Jakarta: Rajawali Pers.

Mertha, I. K. (2010). Politik kriminal dalam penanggulangan tajen (sabungan ayam) di Bali. Udayana University Press.

Moleong, L. J. (1999). Metodologi penelitian. Bandung: PT. Remaja Rosda Karya.

Mudhofir, A. (1996). Teori dan aliran dalam filsafat dan teologi. Gadjah mada University Press.

Ranjabar, J. (2015). Perubahan Sosial: Teori-Teori dan Proses Perubahan Sosial serta Teori Pembangunan. Bandung: Alfabeta.

Setiadi, E. M., \& Kolip, U. (2011). Pengantar sosiologi: pemahaman fakta dan gejala permasalahaan sosial: teori, applikasi dan pemecahannya. Kencana.

Suharsimi, A. (2006). Prosedur penelitian suatu pendekatan praktik. Jakarta: Rineka Cipta.

Veeger, K. J. (1985). Realitas Sosial: refleksi filsafat sosial atas hubungan individu-masyarakat dalam cakrawala sejarah sosiologi. Penerbit PT Gramedia Pustaka Utama.

Wiranata, I. G. A., \& SH, M. (2005). Hukum Adat Indonesia Perkembangan dari Masa ke Masa. Citra Aditya Bakti.

Yesmil, A. Adang.(2013). Sosiologi Untuk Universitas. Bandung: PT Refika Aditama. 


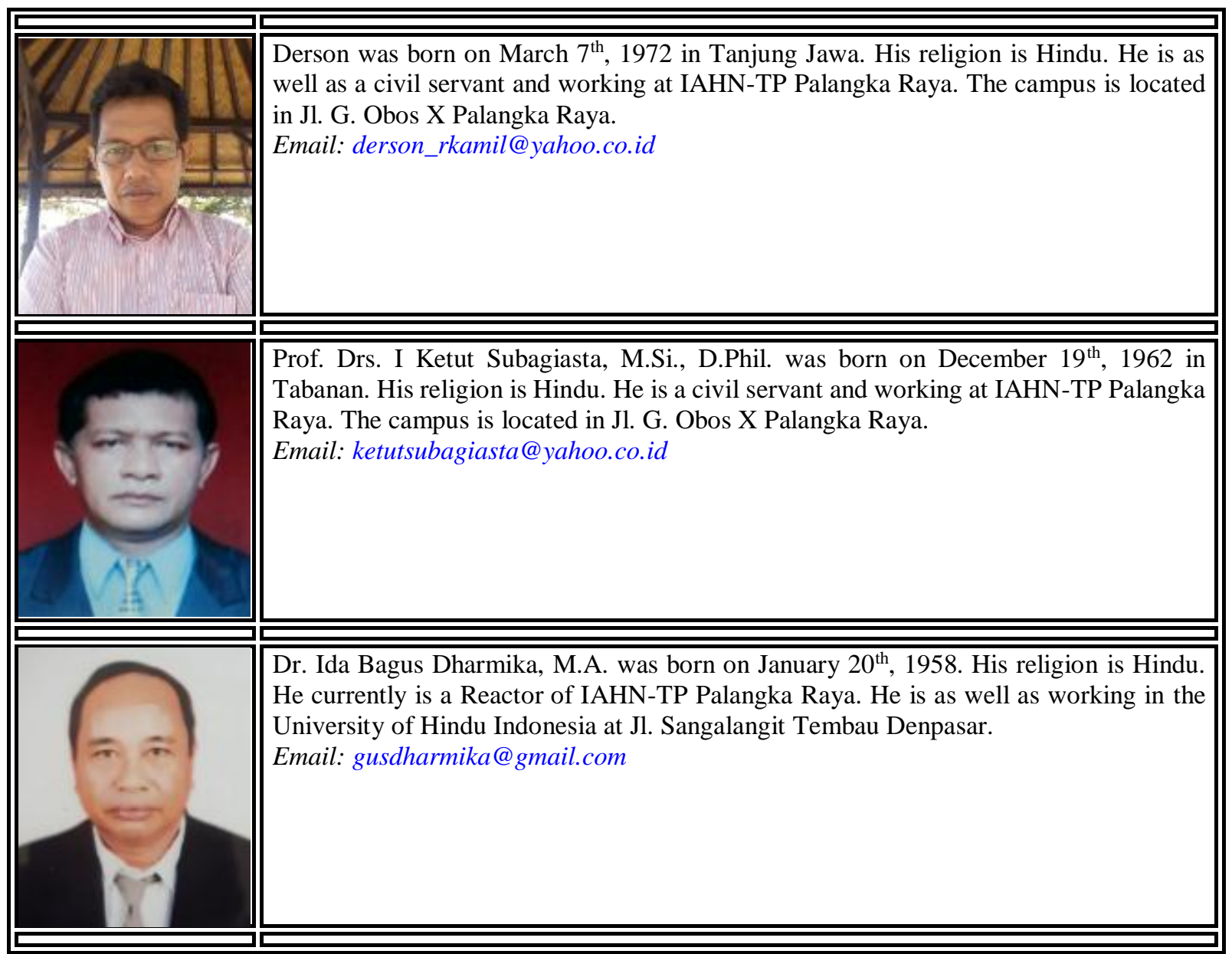

Derson, -, Subagiasta, I. K., \& Dharmika, I. B. (2018). Shifting on Usik Liau game in Wara ceremony towards Hindu Kaharingan society of Dayak Dusun. International Research Journal of Management, IT and Social Sciences, 5(4), 98-105. https://doi.org/10.21744/irjmis.v5n4.271 